\title{
I. ROZPRAWY
}

\author{
SŁAWOMIR PATRYCJUSZ KURSA (Warszawa)
}

\section{Repudium i jego skutki prawne w świetle kodyfikacji Justyniana}

Do form rozwiązania małżeństwa uznanych w prawie justyniańskim należały repudium i divortium. O jednej i drugiej wzmiankuja juź źródła prawa klasycznego. Ich praktyka w czasach cesarzy chrześcijańskich pod wpływem poglądów Ojców Kościoła spotkała się z krytyką i próbami ograniczenia. Justynian, dokonując kodyfikacji prawa rzymskiego, postawił sobie jako jeden z celów reformę przepisów prawa małżeńskiego, także w zakresie ustawodawstwa rozwodowego. Reforma ta w przedmiocie repudium miała dwa etapy:

1) etap recepcji konstytucji jego poprzedników, które dążyły do ograniczenia rozpadu małżeństw poprzez repudium i nieznacznych modyfikacji starego prawa $\mathrm{w}$ tym zakresie;

2) etap nowelizacji skodyfikowanego prawa rozwodowego.

Na uwagę zasługuje argumentacja, która towarzyszyła tej reformie. Niniejszy artykuł dotyczy problematyki repudium na etapie kodyfikacji.

I. Pojęcie i forma repudium. Prawo justyniańskie, chociaż posługuje się terminem divortium także w odniesieniu do repudium ${ }^{1}$, rozróżnia jedno od drugiego, podając differentiam specificam obydwu pojęć ${ }^{2}$. Pierwsza różnica między divortium i repudium została wyeksponowana w tytule drugim księgi dwudziestej czwartej Digestów De divortiis et repudiis w drodze przywołania fragmentu z jedenastej księgi komentarza Gajusa do edyktu prowincjonalnego:

Divortium autem vel a diversitate mentium dictum est vel quia in diversis partes eunt, qui distrahunt matrimonium. In repudiis autem, id est renuntiatione [...]

${ }^{1}$ D. 24,2,3 (Paulus, lib. 34 ad edictum): ...per calorem misso repudio si brevi reversa uxor est, nec divortisse videtur.

${ }^{2}$ Por. L. Caes, La terminologie du divorce dans les textes juridiques latins et les constitutions grecques de Justinien, w: Scrinium Lovaniense. Mélanges historiques Etienne Van Cauwenbergh, Louvain 1961, s. 167-180. 
[Termin] rozwód wywodzi się albo z niezgodności charakterów albo z tego, że ci, którzy rozwiązują małżeństwo, rozchodzą się w różne strony. Przy jednostronnym oddaleniu zaś, to znaczy wypowiedzeniu umowy [małżeńskiej] [... $]^{3}$.

W świetle przywołanego źródła polegała ona na tym, że divortium miało charakter dwustronny, a repudium jednostronny.

W Nov. 117,10 Justynian, zakazując, poza wypadkiem wstapienia do klasztoru, dokonywania divortium, wskazuje na jego istotę, którą stanowiło zgodne porozumienie stron co do rozwiązania małżeństwa ${ }^{4}$. Z natury rzeczy zgoda taka nie była wymagana przy repudium.

Na drugą różnicę wskazuje D. 50,16,191 zaczerpnięty z trzydziestej piątej księgi komentarza Paulusa do edyktu:

Inter 'divortium' et 'repudium' hoc interest, quod repudiari etiam futurum matrimonium potest, non recte autem sponsa divortisse dicitur, quod divortium ex eo dictum est, quod in diversas partes eunt qui discedunt.

Między rozwodem i jednostronnym oddaleniem zachodzi taka różnica, że jednostronnego oddalenia można dokonać także przed zawarciem przyszłego małżeństwa, dlatego nieprawidłowo mówi się, że narzeczona rozwiodła się, ponieważ [termin] rozwód wywodzi się z tego, że ci, którzy rozwiązują małżeństwo, rozchodzą się w różne strony ${ }^{5}$.

Z fragmentu tego wprost wynika, że repudium stosowano ne tylko do rozwiązania małżeństwa, ale także do zerwania zaręczyn ${ }^{6}$.

Jeśli następowało zgodne z prawem divortium lub repudium po zawarciu małżeństwa, skutek był ten sam - małżeństwo ulegało rozwiązaniu.

W literaturze przedmiotem dyskusji jest forma repudium w prawie justyniańskim ${ }^{7}$. M. Talamanca zauważa, że na wschodzie Imperium przyjęła się pisemna forma repudium, natomiast Zachód, jak się wydaje znał także możliwość deklaracji słownej w obecności świadków ${ }^{8}$.

${ }^{3}$ D. $24,2,2$ pr.-1.

${ }^{4}$ Podobnie D. 50,16,101,1.

${ }^{5}$ R. Yaron, Divortium inter absentis, RHD 31 (1963), s. 61: „Divortium facere would not be quite exact for the dissolution of a betrothal; renuntiationem facere may be a more likely possibility".

${ }^{6}$ Nov. 117,10: Quia vero et ex consensu aliqui usque ad praesens alterna matrimonia solvebant, hoc de cetero fieri nullo sinimus modo, nisi forte quidam castitatis concupiscentia hoc fecerint ... Zob. R. Bonini, Il divorzio consensuale dalla Novella Iustiniani 117,110 alla Novella Iustini 140, BIDR 75-76 (1972-73), s. 41 i n.

${ }^{7}$ C.Z. Mehesz, Repudium Romanum, „Revista Juridica” 22 (1971), s. 107-152; ostatnio na temat formy repudium pisała J. Misztal-Konecka, Bigamia w prawie rzymskim, Lublin 2011, s. $177-179$.

${ }^{8}$ M. Talamanca, Istituzioni di diritto romano, Milano 1990, s. 142. 
O formie pisemnej jednostronnego oddalenia małżonka, to jest libellus repudii, wzmiankuje konstytucja cesarzy Dioklecjana i Maksymiana, przywołana w Kodeksie justyniańskim:

C. 5,17,6 (Impp. Diocletianus et Maximianus AA. Phoebo): Licet repudii libellus non fuerit traditus, vel cognitus marito, dissolvitur matrimonium.

Małżeństwo ulega rozwiązaniu, chociażby list oddalający nie był przekazany mężowi lub poznany przez niego.

Innych form repudium nie wyklucza, jak się zdaje, zamieszczony w D. 48,5,44(43) tekst Gajusa z trzeciej księgi komentarza do ustawy XII tablic, w którym czytamy:

Si ex lege repudium missum non sit et idcirco mulier adhuc nupta esse videatur...

Dopóki zgodnie z prawem oddalenie nie zostało wysłane, tak długo z tego powodu należy uważać, że kobieta jest mężatką...9

Tekst ten, a ściślej mówiąc użyty w wyrażeniu missum non sit $\mathrm{w}$ formie biernej czasownik mittere, jest wieloznaczny i nie determinuje formy jednostronnego oddalenia. Oświadczenie woli o zerwaniu związku małżeńskiego składane drugiej stronie mogło być zatem dokonywane na różne sposoby. Pozostaje kwestią otwarta, czy było ono dokonywane w formie słownej bezpośrednio przez małżonka dokonującego repudium, czy przekazywano je w tej formie przez nuncjusza, czy też wolę tę oddalający wyrażał na piśmie.

O słowach, które były używane w takim przypadku wzmiankuje Cycero w „Filipikach” (Philippicae), gdzie odnajdujemy zdanie:

...illam suam rem sibi habere iussit ex xii tabulis, claves ademit, exegit...

nakazał, by zabrała sobie swoją rzecz na podstawie XII tablic, oddała klucze, odeszła ${ }^{10}$.

Praktykę stosowania tych słów potwierdza również Gajus w jedenastej księdze komentarza do edyktu prowincjonalnego, której fragment został zamieszczony w D. 24,2,2,1 (Gaius, lib. 11 ad edictum provinciale):

In repudiis autem, id est, renuntiatione, comprobata sunt haec verba: Tuas res tibi habeto; item haec: Tuas res tibi agito.

${ }^{9}$ Zob. komentarz J. Urbanika do D. 48,5,44(43); J. Urbanik, Formalność rozwodu w rzymskim prawie klasycznym, „Zeszyty Prawnicze” 9.1 (2000), s. 116 i n.

${ }^{10}$ Cic. Phil. 2,28,69. 
Przy jednostronnym oddaleniu zaś, to znaczy oznajmieniu [o rozwiązaniu małżeństwa], potwierdzone są te słowa: zatrzymaj sobie twoje rzeczy; jak również te: rób sobie [co chcesz z] twoimi rzeczami.

W komedii „Amfitrion” (Amphitrio) Plaut wkłada analogiczne słowa w usta kobiety, która grozi odejściem od męża. W trzecim akcie wspomnianej sztuki oburzona oskarżeniami męża Alkimena wypowiada następujące słowa: $V a$ leas, tibi habeas res tuas, reddas meas (Bądź zdrów, trzymaj twoje rzeczy, oddaj [co] moje) ${ }^{11}$. Zgodność między przywołanymi tekstami dowodzi, że tradycja używania tego rodzaju słów przy dokonywaniu repudium sięgała ustawy XII tablic, była w powszechnej praktyce i została uznana w prawie justyniańskim $^{12}$.

Justynian nie uważał bynajmniej, by wypowiedzenie tych słów bezwzględnie przesądzało o ustaniu małżeństwa, jeżeli były wypowiedziane w gniewie. Uznał bowiem za zasadne przytoczenie wypowiedzi Paulusa, która znajduje się w D. 24,2,3 (Paulus, lib. 35 ad edictum):

Divortium non est nisi verum, quod animo perpetuam constituendi dissensionem fit. Itaque quinquid in calore iracundiae vel fit vel dicitur, non prius ratum est, quam si preseverantia apparuit iudicium animi fuisse: ideoque per calorem misso repudio si brevi reversa uxor est, nec divortisse videtur.

Wynika z niej, że repudium było jedynie wówczas skuteczne, gdy zostało dokonane z zamiarem trwałego zerwania. Dlatego to wszystko, co się działo lub wypowiadało $\mathrm{w}$ gniewnym wzburzeniu, nie powodowało wcześniej rozwiązania małżeństwa, chyba że wytrwałość w postanowieniu pokazała, że miała miejsce świadoma decyzja. Justynian podzielał również pogląd Paulusa, że nie wydaje się, by doszło do rozejścia się małżonków wskutek dokonania repudium $\mathrm{w}$ gniewie, jeżeli w krótkim czasie żona powróciła do męża ${ }^{13}$.

Źródła prawa justyniańskiego dowodzą, że repudium mógł dokonać nie tylko każdy z małżonków, lecz również osoba trzecia, to jest ojciec któregoś z małżonków. Świadczy o tym D. 24,2,4, gdzie Justynian przytacza opinię Ulpiana zawierającą stanowisko Juliana $\mathrm{z}$ osiemnastej księgi jego digestów. Julian pyta się tam, czy osoba chora umysłowo mogła oddalić swojego małżonka

${ }^{11}$ Plaut. Amph. 3,2,47. A. Watson zauważa, że Alkimena, dokonując repudium, użyła formuły zastrzeżonej dla męża; zob. idem, The law of persons in the later Roman Republic, Oxford 1967, s. 52. A. Tarwacka skłania się ku temu, że Alkimena jedynie odgraża się używając tych słów, bo ,ilekroć u Plauta żona występuje z inicjatywą rozwodową, ma to na celu efekt komiczny, a nie jest odzwierciedleniem faktycznej sytuacji prawnej"; zob. eadem, Ei foras, mulier, czyli rozwód w komediach Plauta, „Zeszyty Prawnicze” 4.1 (2004), s. 22.

${ }^{12}$ Zob. F. Baudry, s.v. Divortium, w: DAGR 2.1, s. 323; R. Yaron, Minutiae on Roman divorce, RHD 28 (1960), s. $1 \mathrm{nn}$.

${ }^{13}$ Por. D. $50,17,48$. 
i czy sama mogła być oddalona. Na postawione pytanie odpowiedział, że osoba taka może być jednostronnie oddalona, ponieważ uważa się ją za nieświadomą. Oddalić zaś jednostronnie nie może ani sama, ani przez swojego kuratora, jednakże może dokonać tego jej ojciec. W końcu przytoczonego fragmentu podkreśla, że o repudium nie można by było mówić, gdyby nie uznało się, że może trwać małżeństwo z osobą chorą psychicznie ${ }^{14}$.

II. Doktryna chrześcijańska a repudium. Obejmując tron cesarski, Justynian zastał praktykę zarówno repudium, jak i divortium. Nie była to dla cesarza, który stanowił prawo w imię Boże $\mathrm{e}^{15}$, sytuacja komfortowa, biorąc pod uwagę fakt, że w VI wieku po Chrystusie doktryna chrześcijańska na temat nierozerwalności małżeństwa była już dostatecznie wykształcona.

Ojcowie Kościoła i pisarze chrześcijańscy już w II wieku jednoznacznie wypowiadali się na ten temat ${ }^{16}$. Pierwszy komentarz odnośnie do nierozerwalności małżeństwa, jaki zachował się do czasów współczesnych, pochodzi od Hermasa. Zawiera on stanowcze zdanie, że jeżeli mężczyzna „odprawiwszy żonę poślubi drugą, on także popełni cudzołóstwo"17. Podobnie Justyn w swojej Apologii pisał: „kto się żeni z niewiastą oddaloną przez innego męża, popełnia cudzołóstwo [...] Tak więc ci, którzy na mocy prawa ludzkiego zawierają drugie małżeństwo oraz ci, którzy pożądliwie patrzą na niewiastę są grzesznikami w rozumieniu naszego Boga" ${ }^{\prime 18}$. Klemens Aleksandryjski wyjaśniał: „kto bierze kobietę rozwiedzioną, czyni z niej nierządnice” ${ }^{19}$. Według Tertuliana jedynie śmierć jednego z małżonków mogła rozwiązać małżeństwo $^{20}$. Orygenes przypominał: „Zbawca nasz powiedział, że nigdy nie można rozwiązywać małżeństwa, z jakiegokolwiek przestępstwa, tylko w wypadku, gdy kobieta zostanie pochwycona na cudzołóstwie. Powiedział bowiem: każ-

${ }^{14}$ Zdaniem E. Volterry „l'affermazione del passo che il ripudio del padre della donna scioglie il matrimonio sembra rispecchiare la dottrina postclassica del consenso iniziale". Zob. E. Volterra, Ancora sulla struttura del matrimonio classico, w: De iustitia et iure. Festgabe U. von Lubtow, BerlinMünchen 1980, s. 151. Zob. także J. Urbanik, Kilka uwag na temat domniemanych interpolacji justyniańskich, w: Honeste vivere... Księga pamiatkowa ku czci Profesora Władysława Bojarskiego, red. E. Gajda, A. Sokala, Toruń 2001, s. 271.

${ }^{15}$ Zob. chociażby Constitutio Tanta (In nomie domini dei nostri Ihesu Christi); Constitutio Imperatoriam, Constitutio Cordi oraz pierwsze słowa Kodeksu z 534 roku (In nomine domini nostri Ihesu Christi).

${ }^{16}$ Zob. W. Myszor, Matżeństwo i rozwód w ocenie pisarzy chrześcijańskich II i III wieku, w: Rodzina $w$ społeczeństwach antycznych $i$ wczesnym chrześcijaństwie, red. J. Jundziłł, s. 241-247; E. Gajda, Adulterium a trwałość matżeństwa we wczesnym Kościele, w: Rodzina w społeczeństwach antycznych..., s. 267-269.

${ }^{17}$ Hermas, Pastor, IV,1,4.

${ }^{18}$ Justyn, Apologia I,15.

${ }^{19}$ Klemens Al., Stromata II,23.

${ }^{20}$ Tertulian, De monogamia 9; Ad uxorem 1,7; zob. też G. Zannoni, Unità et indissolubilità del matrimonio in Tertuliano, „Apollinaris” 33(1960), s. 297-320. 
dy, kto oddala swoja żone - poza wypadkiem nierzqdu - naraża ja na cudzołóstwo (Mt. 5,32)"21.

Na przełomie IV i V wieku wielu biskupów zachodnich ostro krytykowało fakt, że prawo państwowe niedostatecznie karze za repudia i powtórne małżeństwa tych, którzy w ten sposób się rozwiedli. Jednym z nich był Ambroży, biskup Mediolanu. Według niego rozwiązanie małżeństwa powagą ludzką było wyrazem sprzeciwu wobec woli Bożej, dlatego mąż nie mógł oddalać żony, a oddalona żona nie mogła ponownie wyjść za mąż i vice versa ${ }^{22}$.

Hieronim, zauważając różnicę między prawem cesarskim i Chrystusowym (aliae sunt lege Cesarum, aliae Christi) ${ }^{23}$, stanowczo twierdził, że „cudzołożnicą jest niewiasta, która za życia męża wychodzi za innego. Dopóki mąż żyje, choćby był cudzołożnikiem, czy sodomitą, choćby był obarczony wszelkimi występkami i z powodu tych przestępstw opuszczony przez żonę, uważany jest za męża tej, której innego męża brać nie wolno"24.

Także Augustyn uważał, że oddalenie współmałżonka nie daje prawa do zawarcia kolejnego małżeństwa ${ }^{25}$, czyli nie powoduje ustania pierwszego, a cudzołóstwo któregoś z małżonków stanowi jedynie powód do separacji ${ }^{26}$.

Kościół pierwszych wieków był w tej kwestii dość zgodny, gdyż nie tylko Ojcowie Kościoła zachodniego, lecz także Ojcowie greccy stali na stanowisku, że oddalenie małżonka nie uprawnia do powtórnego małżeństwa ${ }^{27}$. Warto odnotować w tym miejscu pogląd Jana Chryzostoma z jego dzieła De libello repudii, który cechuje wyraźna awersja do ustawodawstwa państwowego dopuszczającego repudia i rozwody: „Nie mów mi o prawach, które pozwalają dać list rozwodowy i rozwodzić się; Bóg na sądzie ostatecznym nie będzie sądził według tych praw, ale według praw swoich, które dla ludzi ustanowił"28.

Odbicie owej doktryny znajdujemy w kanonach pierwszych synodów partykularnych i soborów powszechnych, które również uznawały małżeństwo

${ }^{21}$ Orygenes, Komentarz do Mateusza, 19,3-12; zob. też H. Pietras, Orygenes o malżeństwie i rozwodzie, w: W stużbie czlowiekowi. Studium duszpastersko-katechetyczne, Z. Marek (red.), Kraków 1991, s. 173-183.

22 Ambroży, Expositionis evang. sec. Lucam, VIII,5. Zob. P. Laurence, La castitas féminine dans le Code Théodosien: rencontre entre l'Église et l'État?, w: Empire chrétien et Église aux IVe et Ve siècles. Intégration ou «concordat»? Lé témoignage du Code Théodosien, red. J.-N. Guinot, F. Richard, Paris 2008, s. 380

${ }^{23}$ Hieronim, Epistulae, 77,3.

${ }^{24}$ Ibidem, 55,4.

${ }^{25}$ Negował także ważność kanoniczną oddalenia żony z powodu jej bezpłodności dozwolonego przez prawo cywilne. Zob. R. Astolfi, Sintesi della storia della bigamia in Roma, SDHI 76 (2010), s. 288.

${ }^{26}$ Augustyn, De coniugis adulterinis, I,2. Zob. też A. Eckmann, Święty Augustyn o matżeństwie i dziewictwie, w: Pisma świętego Augustyna o malżeństwie i dziewictwie. Przekład i komentarz, A. Eckmann (red.), Lublin 2003, s. 5-49.

${ }^{27}$ Bazyli, Epistolae, 188,9; Grzegorz z Nazjansu, Orationes, 73,6.

${ }^{28}$ Jan Chryzostom, De libello repudii, 1. 
chrześcijan zasadniczo za nierozerwalne, a jeśli dopuszczały oddalenie małżonka, to tylko w przypadku cudzołóstwa, ale bez rozwiązania węzła małżeńskiego $^{29}$, aczkolwiek wschodnie ustawodawstwo synodalne kierując się racjami duszpasterskimi, uznawało pokutę tych, którzy zawarli związki małżeńskie po raz drugi $(\beta \imath \gamma \alpha \mu o \imath)^{30}$.

Doskonale obrazuje taki punkt widzenia kan. 102 jedenastego synodu w Kartaginie z 407 roku:

Placuit, ut secundum evangelicam et apostolicam disciplinam, neque dimissus ab uxore, neque dimissa a marito, alteri coniugatur; sed ita maneant, aut sibimet reconcilientur: quod si contempserint, ad poenitentiam redigantur. In qua causa legem imperialem petendum est promulgari.

Postanawia się, aby zgodnie $\mathrm{z}$ ewangeliczną $\mathrm{i}$ apostolską nauką, ani oddalony przez żonę, ani oddalona przez męża, nie poślubiali innych; lecz w tym stanie niech pozostaja, albo wzajemnie się pojednaja; gdyby zaś temu się sprzeciwili, należy ich przywołać do pokuty. W tej sprawie uprasza się, żeby została ogłoszona cesarska ustawa.

Z tekstu wynika, że zgromadzeni na synodzie biskupi zdawali sobie sprawę z istniejącej rozbieżności między prawem kanonicznym i państwowym i próbowali wpłynąć w ten sposób na cesarza, by dostosował normy prawa państwowego do nauki chrześcijańskiej ${ }^{31}$.

Jak widać, Kościołowi V wieku nie wystarczała aprobata dla małżeństwa monogamicznego, lecz dążył on do wprowadzenia głoszonej zasady nierozerwalności małżeństwa do prawodawstwa stanowionego przez cesarzy.

Justynian, podobnie jak jego poprzednicy, czuł brzemię tej presji. Miał także świadomość, że jego poprzednikom jedynie częściowo udało się ograniczyć zjawisko rozpadu małżeństw. Decydując się później w Nowelach na reformy prawa w tym zakresie, wiedział, że odnośnych praw jego poprzedników powszechnie nie przestrzegano, co więcej, interpretowano je dowolnie. Ponadto trzeba pamiętać, że repudium, jako takie, było bardzo mocno zakorzenione w kulturze ludzi Bliskiego Wschodu, a jego praktyka sięgała odległych czasów Starego Testamentu ${ }^{32}$. Także w Rzymie, o czym wzmiankuje Seneka, repudia były zjawiskiem częstym. Bywało, że kobiety liczyły swoje lata nie według urzędowania konsulów, lecz według liczby byłych mężów ${ }^{33}$. Podszedł więc do

${ }^{29}$ Kan. 10 synodu w Arles: Ut is, cuius uxor adulteraverit, alia illa vivente non accipiant; kan. 8 synodu w Nicei.

${ }^{30}$ Kan. 1 synodu w Laodycei. Zob. W. Góralski, Pierwotna dyscyplina Kościoła w sprawie matżeństwa, „Roczniki Teologiczno-Kanoniczne” 30(1983), z. 5, s. 78-80.

${ }^{31}$ Zob. W. Panecki, Secundae nuptiae $w$ życiu i prawie starożytnych chrześcijan, „Prawo Kanoniczne" 14(1971), nr 1-2, s. 259; W. Góralski, Pierwotna dyscyplina Kościoła ..., op. cit., s. 82.

${ }^{32}$ Mt. 19,3.

${ }^{33}$ Seneca, De benef., 3,16,2. 
reformy prawa rzymskiego w tym zakresie w sposób pragmatyczny i postanowił działać metodą drobnych kroków, rozpoczynając od usystematyzowania norm prawnych wydanych przede wszystkim przez cesarzy chrześcijańskich.

III. Motywy reformy prawa dotyczącego repudium. Pierwszym motywem działalności Justyniana na tym polu była chęć zebrania wszystkich norm ograniczających praktykę jednostronnego oddalania małżonków, które wydali jego poprzednicy. W ten sposób pragnął osiągnąć większą praworządność w państwie. Zebranie tych norm miało także charakter prewencyjny w stosunku do mało odpowiedzialnych małżonków i miało służyć zapobieżeniu pochopnego rozwiązywania przez nich małżeństw i tym samym destabilizacji podstawowej komórki społecznej, jaką jest rodzina.

Drugim motywem była wola utrudnienia rozwiązywania małżeństw ze względu na dobro dzieci (favor liberorum), które po raz pierwszy podnieśli w swojej konstytucji cesarze Teodozjusz II i Walentynian w 449 roku $^{34}$. Utrzymując znaczenie tego motywu, Justynian implicite dawał społeczeństwu do zrozumienia, że repudium stanowiło przeszkodę do osiągnięcia jednego z podstawowych celów małżeństwa, jakim jest dobre wychowanie dzieci. Wychowanie to było dla Justyniana naturalnym obowiązkiem rodziców ${ }^{35}$. Zdawał bowiem sobie sprawę z tego, że bardziej bowiem niż inne działania, wychowanie wymaga współpracy rodziców, których rola jest nie do zastapienia, a dzieło ich troski i miłości, jeśli trwa całe życie, czyni ich wysiłki bardziej skutecznymi.

Trzecim motywem była chęć uzgodnienia prawa państwowego z chrześcijańską doktryną i prawem kanonicznym w kwestii nierozerwalności małżeństwa i walorów cnoty czystości.

IV. Klasyfikacja i przesłanki repudium. Wzorem poprzedników Justynian dokonał klasyfikacji repudium, wyróżniając repudium propter iustam causam (culpabilem), repudium bona gratia i repudium sine causa.

1. Repudium proter iustam causam (culpabilem). Justynian w trwałości małżeństwa dostrzegał dobro, a repudium traktował jako zło konieczne. Świadczy o tym chęć ograniczenia jego występowania poprzez wskazanie negatywnych przesłanek, zależnych od woli ludzkiej, które odbierały rację podtrzymywania związku małżeńskiego, jako że destrukcyjnie wpływały na consortium omnis vitae et educationem prolis.

Kierując się tymi racjami, postanowił w C. 5,17,8 podtrzymać w mocy katalogi zawinionych przyczyn określonych przez Teodozjusza II i Walentynia-

${ }^{34}$ C. 5,17,8 pr.; zob. H. Insadowski, Rzymskie prawo matżeńskie a chrześcijaństwo, Lublin 1935, s. 292.

${ }^{35}$ I. 1,2 pr. 
na, które usprawiedliwiały dokonanie repudium. Pierwszy z nich dotyczył zachowań zawinionych ze strony mężczyzny, a drugi ze strony kobiety ${ }^{36}$.

Według C. 5,17,8,2 żona mogła oddalić męża, jeżeli dopuścił się on cudzołóstwa, zabójstwa, trucicielstwa, spiskowania przeciwko cesarzowi, fałszerstwa, bezczeszczenia grobów, sacrilegium, rozboju lub ukrywania rozbójników, kradzieży bydła albo uprowadzenia ludzi, odbywania schadzek z bezwstydnymi kobietami, nastawania na życie żony za pomocą trucizny, broni albo w jakiś inny sposób lub jej bicia (co było zabronione w stosunku do kobiet wolnourodzonych).

Z kolei mężowi wolno było jednostronnie oddalić swoją żonę, jeżeli udowodnił, że była ona winna jednego z następujących czynów: cudzołóstwa, trucicielstwa, zabójstwa, uprowadzenia, bezczeszczenia grobu, sacrilegium, współudziału w rozboju, brania udziału w ucztach z obcymi mężczyznami bez wiedzy lub wbrew jego woli, nocowania poza domem wbrew jego woli i uzasadnionej przyczyny, uczestniczenia bez jego zgody w igrzyskach lub spektaklach organizowanych w cyrkach lub na arenach, nastawania na jego życie z użyciem trucizny, broni lub w jakikolwiek inny sposób, bycia wspólniczką w spisku przeciwko cesarzowi, dopuszczenia się wspólnictwa w przestępstwie fałszerstwa lub zuchwałego podniesienia na niego ręki ${ }^{37}$.

Jeżeli list rozwodowy zawierał oskarżenie o przestępstwo cudzołóstwa lub obrazę majestatu, dla zbadania sprawy oddalenia należało, jeżeli nie można było dostarczyć innych dokumentów, przesłuchać dojrzałych niewolników obojga płci. Także w przypadku uprowadzenia człowieka dokonanego przez któregoś z małżonków stosowano te same środki dowodowe ${ }^{38}$.

Do wyżej wymienionych powodów Justynian dodał trzy inne, również pochodzące $\mathrm{z}$ dawnego prawa, a mianowicie: rozmyślne przerwanie ciąży, lubieżna kąpiel z mężczyznami, czynienie obietnic małżeństwa innym mężczyznom podczas trwania ważnego związku małżeńskiego ${ }^{39}$.

Mężczyzna stanu wolnego nie mógł do swojego domu przyjąć obcej żony, która nie dokonała formalnie repudium, bez narażenia się na oskarżenie o popełnienie cudzołóstwa z nią. Justynian w D. 24,2,8 uznał takie zachowanie za zasługujące na karę, stosownie do przytoczonej tam opinii Papiniana z jego księgi de adulteris. W świetle tej opinii mężczyzna, który wziął do swojego domu cudzą żonę, a ta dopiero $\mathrm{z}$ jego domu dokonała repudium swojego męża, był relegowany na okres trzech lat.

Z powyższego wynika, że katalogi zawinionych przyczyn repudium nie były ze sobą tożsame, choć w większej części się pokrywały. Ich rozróżnienie ze względu na sexus uzasadniała specyfika czynów zabronionych, których za-

${ }^{36} \mathrm{Na}$ każdy z katalogów, jak zauważa E. Volterra, składało się po czternaście przyczyn; zob. E. Volterra, s.v. Divorzio (diritto romano), w: Novissimo Digesto Italiano, t. VI, Torino 1960, s. 64.

${ }^{37}$ C. $5,17,8,3$.

${ }^{38}$ C. $5,17,8,6$.

${ }^{39}$ C. $5,17,11,2$. 
istnienie warunkowało dokonanie legalnego repudium. Justynian przytoczył je w Kodeksie in extenso.

2. Repudium bona gratia. Oprócz możliwości jednostronnego oddalenia małżonka na podstawie negatywnej przesłanki, jaką stanowiła prawnie uznana causa culpabilis repudii, prawo justyniańskie, wzorując się na wcześniejszych rozwiązaniach prawnych, dopuszczało możliwość jednostronnego rozwiązania małżeństwa z godziwej przyczyny. W tym przypadku chodziło o takie okoliczności, które usprawiedliwiały repudium, chociaż żadna ze stron nie dopuściła się jakiejkolwiek winy.

W prawie przedjustyniańskim wymieniano pięć takich okoliczności, uznanych także w Digestach:

1) kapłaństwo,

2) bezpłodność ${ }^{40}$,

3) podeszły wiek,

4) zły stan zdrowia, w szczególności choroba umysłowa,

5) służba wojskowa ${ }^{41}$.

Okoliczności te zdaniem Hermogeniana stanowiły podstawę rozwiązania małżeństwa bona gratia ${ }^{42}$. Znajdując się w tych okolicznościach, strona, która nie widziała perspektywy utrzymania małżeństwa aż do śmierci, miała prawo zrezygnowania $\mathrm{z}$ takiego związku w drodze repudium.

Ad 1) Zarówno źródła kościelne, jak i prawa rzymskiego, potwierdzają praktykę oddalania legalnie pojętych żon przez duchownych różnych stopni, począwszy od subdiakonów, a skończywszy na biskupach. Świadczy o tym Epistola ad rusticum Leona I Wielkiego, w której wspomniany papież pisze, że duchowni, którzy ożenili się przed przyjęciem święceń, nie są więcej zobowiązani do oddalania swych żon. Niemniej, słudzy ołtarza powinni żyć ze swoimi żonami tak, jakby ich nie mieli, czyli we wstrzemięźliwości ${ }^{43}$. Podobnie konstytucja cesarzy Honoriusza i Teodozjusza II z 420 roku zakazywała duchownym wszystkich stopni oddalania swoich żon pod pretekstem potrzeby zachowania czystości:

Illas etiam non relinqui castitatis hortatur adfectio, quae ante sacerdotium maritorum legitimum meruere coniugium.

${ }^{40}$ D. 24,1,60,1 (Hermogenianus, lib. 2 iuris epitomarum): Divortii causa donationes inter virum et uxorem concessae sunt: saepe enim evenit, uti propter sacerdotium vel etiam sterilitatem ( $\mathrm{Z}$ racji rozejścia się dozwolone są darowizny między mężem i żoną. Zdarza się to bowiem często, jak na przykład z powodu kapłaństwa lub bezpłodności).

${ }^{41}$ D. 24,1,61 (Gaius, lib. 11 ad edictum provincionale): vel senectutem aut valetudinem aut militiam satis commodo retineri matrimonium non possit (lub starości albo choroby, albo wojska nie można z łatwością utrzymać małżeństwa).

${ }^{42}$ D. 24,1,62 (Hermogenianus, lib. 2 iuris epitomarum): Et ideo bona gratia matrimonium dissolvitur (I dlatego z godziwej przyczyny małżeństwo się rozwiązuje).

${ }^{43}$ Leon I, Epistola ad rusticum, III. 
Również pragnienie czystości nie może zachęcać do porzucenia tych [kobiet], które przed kapłaństwem mężów weszły w legalne związki małżeńskie ${ }^{44}$.

Fakt przytoczenia w Digestach fragmentu pochodzącego od Hermogeniana świadczy, że Justynian aprobował praktykę, która nie była ani po myśli papieża Leona I, ani po myśli Honoriusza i Teodozjusza II. Swój stosunek do wcześniejszych konstytucji odnoszących się do małżeństwa duchownych Justynian wyraził w C. 1,3,41(42),2-4. Pisał tam, że od godności biskupiej powinni być wykluczeni nie tylko żonaci, ale i ci, co mają dzieci lub wnuki, ponieważ największą część codziennego życia zabiera im opieka nad nimi, która nie pozwala na rzetelne pełnienie obowiązków duchownych. Ponadto, miłość do dzieci uniemożliwia im ojcostwo duchowe względem wiernych. Wydaje się, że dopuszczając możliwość rozwiązania małżeństwa z powodu kapłaństwa, Justynian okazał zrozumienie także dla żon duchownych, którym prawo kanoniczne zabraniało współżycia seksualnego po przyjęciu święceń i w konsekwencji sprowadzało je do roli gospodyń domowych.

Ad 2) Sterilitas, czyli bezpłodność mogła wystąpić zarówno u mężczyzn ${ }^{45}$, jak i u kobiet ${ }^{46}$. Mężczyzn dotkniętych bezpłodnością juryści rzymscy nazywali spadones bez względu na to, czy się takimi urodzili, czy też takimi się stali z jakiegoś innego powodu, na przykład kastracji ${ }^{47}$.

Nie wzbraniała ona w prawie justyniańskim zawarcia małżeństwa, co wynika ze słów Ulpiana, które zostały umieszczone w D. 28,2,6 pr. (Ulpianus, lib. 3 ad Sabinum):

Sed est quaesitum, an is, qui generare facile non possit, postumum heredem facere possit. et scribit Cassius et Iavolenus posse: nam et uxorem ducere et adoptare potest. spadonem quoque posse postumum heredem scribere et Labeo et Cassius scribunt: quoniam nec aetas nec sterilitas ei rei impedimento est.

Powstaje pytanie, czy ten, który nie mógłby łatwo począć, mógłby ustanowić dziedzicem pogrobowca? Zarówno Kasjusz, jak i Jawolenus piszą, że mógłby, ponieważ może i pojąć żonę, i adoptować. I Labeo, i Kasjusz piszą, że bezpłodny także może ustanowić dziedzicem pogrobowca, ponieważ ani wiek, ani bezpłodność $\mathrm{w}$ tej sprawie nie stanowią przeszkody.

Jednakże należy pamiętać, że według D. 23,3,39,1 małżeństwo zawarte przez kastrata było nieważne (Ulpianus, lib. 33 ad edictum):

${ }^{44}$ C.Th. $16,2,44$.

${ }^{45}$ D. $28,2,6$ pr.

${ }^{46}$ D. $19,1,21$ pr.

${ }^{47}$ D. 50,16,128 (Ulpianus, lib. 1 ad legem Iuliam et Papiam): Spadonum generalis apellatio est: quo nomine tam hi, qui natura spadones sunt, item thlibiae thlasiae, sed et si quod aliud genus spadonum est, continentur. 
Si spadoni mulier nupserit, distinguendum arbitor, castratus fuerit necne, ut in castrato dicas dotem non esse: in eo qui castratus non est, quia est matrimonium, et dos et dotis actio est.

Jeżeli kobieta poślubiłaby bezpłodnego, należy rozróżnić i ocenić, czy był kastratem, czy też nie; gdybyś orzekł, że był kastratem, nie ma posagu, w przypadku zaś gdy nie jest kastratem, ponieważ jest małżeństwo, jest i posag, i powództwo o posag.

Z porównania D. $28,2,6$ pr. i D. $23,3,39,1$ wynika, że podstawę do rozwiązania małżeństwa stanowiła wyłącznie naturalna sterilitas.

Jakkolwiek naturalna bezpłodność mogła być powodem rozwiązania małżeństwa, Justynian nie odważył się określić momentu, od którego strony mogły się na nią powołać. Niewątpliwie potwierdzały ją trwające od dłuższego czasu bezowocne stosunki małżeńskie. Wydaje się jednak, że tylko bezpłodność stwierdzona po zawarciu małżeństwa stanowiła przesłankę do dokonania repudium. Gdyby bowiem małżonkowie wiedzieli o niej przed zawarciem małżeństwa i świadomi tej wady je zawarli, nie mogłaby ona stanowić podstawy dokonania repudium $^{48}$.

Ad 3) Istotna z punktu widzenia zawarcia iustum matrimonium była dolna granica wieku. Chociaż pełnoletniość uzyskiwało się z ukończeniem dwudziestego piątego roku życia, prawo zezwalało zarówno mężczyźnie, jak i kobiecie na zawarcie związku małżeńskiego już po osiagnięciu dojrzałości. W świetle C. 5,4,24 mężczyznę należało uważać za dojrzałego od ukończenia czternastego roku życia, kobietę zaś od ukończenia dwunastego roku życia.

Natomiast z punktu widzenia rozwiązania małżeństwa bona gratia ważna była górna granica wieku. Przypomnieć należy, że do czasów Justyniana obowiązywały przepisy lex Iulia et Papia Poppaea. Nakładała ona obowiązek zawierania małżeństw na mężczyzn, którzy ukończyli dwudziesty piąty rok życia, a nie ukończyli sześćdziesiątego, i na kobiety, które ukończyły dwudziesty rok życia, a nie ukończyły pięćdziesiątego ${ }^{49}$. Nietrudno zauważyć, że te cezury czasowe uwzględniały optymalny okres płodności u mężczyzn i kobiet. Ich wprowadzenie nie oznaczało jednak zakazu zawierania małżeństw po osiagnięciu górnego wieku przewidzianego we wspomnianej ustawie ${ }^{50}$. Niemniej, narusze-

${ }^{48}$ Kłóciłoby się to $\mathrm{z}$ zasadą nullam potest videri iniuriam accipere, qui semel voluit (D. 39,3,9,1). J.P. Néraudau przytacza mowę żałobną na cześć pewnej matrony rzymskiej, w której jej mąż przypomina, że żona świadoma swej bezpłodności nosiła się z zamiarem opuszczenia go. On jednak doceniając jej walory osobiste, nie oddalił jej, chociaż nie mieli ze sobą dzieci. Zob. J.P. Néraudau, Être enfant à Rome, Paris 1996, s. 175.

${ }^{49}$ Ulp. 16,1.

${ }^{50}$ Prawo kanoniczne Kościoła katolickiego nie wprowadziło do prawa małżeńskiego górnej granicy dla zawarcia małżeństwa. W prawosławiu górną granicą wieku dla wstapienia w związek małżeński jest osiemdziesiąt lat dla obojga płci. Ślub w wieku powyżej osiemdziesięciu lat jest wykluczony. Zob. S. Hrycuniak, Prawostawne pojmowanie matżenstwa, Białystok 1994, s. 91. 
niem lex Iulia et Papia Poppaea było zawarcie małżeństwa przez mężczyznę poniżej sześćdziesiątego roku życia z kobietą powyżej lat pięćdziesięciu. Takie małżeństwa nosiły nazwę nierównych (impar matrimonia) i podlegały ograniczeniom $\mathrm{w}$ prawie spadkowym ${ }^{51}$. Justynian zniósł nie tylko ten obowiązek, ale także sankcje za jego nieprzestrzeganie ${ }^{52}$.

Wydaje się, że rozwiązanie małżeństwa bona gratia z powodu starości najprawdopodobniej dotyczyło małżeństw, gdy różnica wieku między małżonkami była dość znaczna, a jedna ze stron nie była w stanie znieść przywar drugiej, takich jak przyzwyczajenia, upór, zgryźliwość, które nierzadko pojawiają się wraz ze starczym wiekiem.

Ad 4) W świetle D. 27,1,10,8 choroba usprawiedliwiała, jeżeli stawała się przeszkodą w realizacji swoich powinności (valetudo excusat, sed ea quae impedimento est, quominus quis suis rebus superesse possit). Przy rozwiązaniu zatem małżeństwa bona gratia $\mathrm{w}$ grę wchodziła tylko taka choroba, która stanowiła rzeczywistą przeszkodę w realizacji obowiązków małżeńskich ${ }^{53}$. Nie mogło chodzić o czasową ułomność ciała, lecz musiała to być choroba, która na stałe uniemożliwiała spełnianie tych obowiązków, czyli kwalifikowała się do uznania jej nie za morbus, lecz za vitium ${ }^{54}$.

W D. 23,2,45,5 Ulpian wzmiankuje o możliwości rozstania się kobiety $\mathrm{z}$ chorym psychicznie mężem.

Wyjaśnić należy, że choroba umysłowa, która ujawniła się u jednego z małżonków w czasie trwania małżeństwa, w zasadzie nie powodowała ustania małżeństwa. Jeżeli jednak dochodziła do takiego stopnia, że nie było żadnej nadziei wyzdrowienia i furiosus zagrażał otoczeniu (sin autem tantus furor est, ita ferox, ita perniciosus, ut sanitatis nulla spes supersit ministros terribilis), stanowiła okoliczność usprawiedliwiającą rozwiązanie małżeństwa bez niczyjej winy (nullius culpa). W takiej sytuacji współmałżonek, czy to powołując się na złośliwość choroby psychicznej, czy też na chęć posiadania dzieci, mógł wysłać nuncjusza i za jego pośrednictwem jednostronnie oddalić chorego psychicznie małżonka ${ }^{55}$.

Ad 5) W tytule de uxoribus militum vel eorum qui rei publicae causa sunt (C. 2,51) Justynian potwierdził i zaaprobował fakt, że żony żołnierzy mogły im towarzyszyć w wyprawach wojennych i podróżach w sprawach państwowych (mulieribus, quae cum maritis rei publicae causa absentibus peregrinatae sunt) ${ }^{56}$.

${ }^{51}$ Ulp. 16,4 .

${ }^{52}$ C. $5,4,27$.

${ }^{53}$ S. Solazzi, Infirmitas aetatis e infirmitas sexus, w: Scritti 3, Napoli 1960, s. 357 i n.

${ }^{54}$ D. 50,16,101,2 (Modestinum, lib. 6 differentiarum): Verum est'morbum' esse temporalem corporis inbecillitatem, 'vitium' vero perpetuum corporis impedimentum, veluti si talum excussit: nam et luscus utique vitiosus est.

${ }^{55}$ D. $24,3,22,7$.

${ }^{56}$ C. 2,51(52),1. 
Taka praktyka, choć znana, nie była powszechna i wiele kobiet musiało cierpieć rozłąkę ze swoimi mężami. Niewątpliwie budowanie consortium omnis vitae z nieobecnym żołnierzem było bardzo utrudnione. Chociaż podtrzymanie affectio maritalis zależało od dwóch stron, prawo justyniańskie nie usprawiedliwiało postawy obojętności męża żołnierza wobec swojej żony. W szczególności żołnierz nie mógł godzić się na jej cudzołóstwo. W przypadku stwierdzenia takiego faktu należało go usunąc $\mathrm{z}$ wojska i deportować ${ }^{57}$.

Każdy żonaty żołnierz był obowiązany starać się o kontakt z żoną per epistulam lub per nuntium. Ustawa Konstantyna z 337 roku, zaaprobowana w C. 5,17,7, stanowiła, że milczenie ze strony żołnierza nie mogło trwać dłużej niż cztery lata. Jeżeli żona przez ten czas nie otrzymała żadnej wiadomości i przestała mieć nadzieję na jej otrzymanie, miała prawo do zawarcia nowego małżeństwa, jednakże nie mogła tego dokonać bez przesłania dowódcy swojego męża listu zawierającego informację o woli rozstania się z mężem. Jeżeli zachowała tę procedurę, jej drugie małżeństwo nie było uważane za potajemne i w konsekwencji nie traciła ona posagu ani nie mogła być skazana na karę główną. Należało jednak zbadać, czy nie istnieje podejrzenie o cudzołóstwo i czy nie doszło do potajemnego związku, aby nie było żadnego niebezpieczeństwa wstydu dla tych, którzy skonsumowali małżeństwo. Jeżeli bowiem ukradkiem, świadomie zostało naruszone łoże małżeńskie, żona była poddana odpowiedniej karze zgodnie z prawem.

Do wymienionych okoliczności Justynian konstytucją z 528 roku, zamieszczoną w C. 5,17,10, dodał nową - utrzymującą się przez dwa lata niezdolność do współżycia małżeńskiego ze strony męża, stwierdzając:

In causis iam dudum specialiter definitis, ex quibus recte mittundur repudia, illam addimus, ut, si maritus uxori ab initio matrimonii usque ad duos continuom annos computandos coire minime propter naturalem imbecillitatem valeat, possit mulier vel eius parentes sine periculo notis amittendae repudium marito mittere, ita tamen, ut ante nuptias donatio eidem marito servatur.

Do przyczyn specjalnie wyżej określonych, z powodu których zgodnie z prawem dokonuje się jednostronnych oddaleń, dodaliśmy tę mianowicie, że gdyby mąż w ciagu dwóch lat od początku małżeństwa nie mógł odbyć stosunku małżeńskiego z żoną z powodu naturalnej słabości, niech wolno będzie kobiecie lub jej rodzicom bez obaw o utratę posagu dokonać względem męża jednostronnego oddalenia, z tym zastrzeżeniem, że darowizna przedmałżeńska ma służyć temuż mężowi.

Następnie konstytucją z 531 roku wprowadził kolejną okoliczność usprawiedliwiającą repudium bona gratia, to jest wybranie życia religijnego, na

${ }^{57}$ D. $48,5,12(11)$ pr. 
przykład wstąpienie do zakonu. W C. 1,3,52,15 wyraźnie zaznaczył, że repudium mógł dokonać małżonek, który nie wybrał życia religijnego.

3. Repudium sine iusta causa. W C. 5,17,8,1 Justynian podtrzymał zakaz rozwiązywania małżeństw $\mathrm{w}$ drodze repudium sine iusta causa, wydany przez cesarzy Teodozjusza II i Walentyniana. Naruszenie tego zakazu nie było jednak obarczone sankcją nieważności. W konsekwencji oddalenie małżonka bez słusznej przyczyny także skutkowało rozwiązaniem małżeństwa, podobnie jak to miało miejsce w przypadku repudium propter causam culpabilem.

Ku wywiedzionej z C. 5,17,8,1 tezie skłania także konstytucja cesarzy Honoriusza i Teodozjusza II z 421 roku:

C. 9,9,34(35) (Impp. Honorius et Theodosius AA. Palladio pp.): Si mulier repudii oblatione sine ulla legitima causa a se dati discesserit: ne viduitatem stupri procacitate commaculet, accusationem repudiato marito iure deferimus.

Jeżeli kobieta odeszłaby [od męża], dokonując oddalenia [go] bez żadnej prawnej przyczyny, zezwalamy oddalonemu mężowi na jej oskarżenie zgodnie z prawem, gdyby dopuszczając się nierządu, skalała stan niezamężny.

Dowodzi jej przede wszystkim użycie w przywołanym tekście terminu stuprum (stosunek pozamałżeński), jak i terminu viduitas (stan niezamężny). Można przypuszczać, że gdyby prawodawca uznał, iż dokonanie repudium sine causa nie powodowało takiego skutku, przyznałby opuszczonemu małżonkowi prawo do oskarżenia kobiety o adulterium (cudzołóstwo) ${ }^{58}$. Ponadto z przytoczonego tekstu wynika, że oddalony mąż nie miał prawa wniesienia oskarżenia przeciwko kobiecie, dopóki nie popełniła ona stuprum.

V. Prawne skutki rozwiązania małżeństwa w drodze repudium. W świetle przytoczonych wcześniej źródeł skutki prawne rozwiązania małżeństwa w drodze repudium obejmowały sankcje majątkowe, które dotyczyły małżonków i sankcje osobiste w stosunku do kobiet oraz zabezpieczenia prawne dla dzieci pochodzących z małżeństwa.

1. Skutki dotyczące malżonków. Dążąc do ograniczenia rozwiązywania małżeństw w drodze repudium, Justynian postanowił obwarować naruszenia

${ }^{58}$ Jednoznacznie na różnicę między stuprum i adulterium wskazuje D. 50,16,101 pr. (Modestinus, lib. 9 differentiarum): Inter 'stuprum' et 'adulterium' hoc interesse quidam mutant, quod adulterium in nuptam, stuprum in viduam committitur... (Między nierządem i cudzołóstwem ta zaś zachodzi różnica, że cudzołóstwo popełnia się względem żony, a nierząd względem [kobiety] niezamężnej...). Zob. G. Kuleczka, Prawo rzymskie epoki pryncypatu wobec dzieci pozamatżeńskich, Wrocław-Warszawa-Kraków 1969, s. 48 
stanowionego przez siebie prawa małżeńskiego stosownymi sankcjami karnymi. Nie wydaje się, by było to przejawem jakiegoś woluntaryzmu z jego strony, lecz jak można się domyślać, powodem tym była wola zagwarantowania skuteczności prawnej stanowionych przepisów prawa. W przeszłości bowiem leges imperfectae, chociażby w przypadku darowizn wśród małżonków, obchodzono na różne sposoby. Będąc tego świadomym, wprowadził do instytucji repudium sankcje karne majątkowe i osobiste. Kary te były zróżnicowane w zależności od okoliczności, w jakich doszło do repudium.

W przypadku rozwiązania małżeństwa propter iustam causam, jeżeli kobieta dowiodła swojemu mężowi wystapienie co najmniej jednej z przyczyn wskazanych w C. 5,17,8,2, miała prawo do zatrzymania zarówno posagu, jak i darowizy ante nuptias ${ }^{59}$. Analogiczne uprawnienia przysługiwały mężczyźnie, który dowiódł, że jego żona dopuściła się czynu zabronionego ujętego w C. $5,17,8,3^{60}$. Gdyby wymienione przysporzenia majątkowe z racji zawarcia małżeństwa nie były w ich dyspozycji, niewinna strona dokonująca repudium miała prawo je windykować ${ }^{61}$. Innymi słowy, małżonek winny repudium tracił wszystkie przysporzenia majątkowe, zarówno wniesione, jak i otrzymane z tytułu zawarcia małżeństwa, na rzecz niewinnego małżonka.

Mężczyzna, który propter iustam causam oddalił swoją żonę, mógł natychmiast poślubić inną kobietę ${ }^{62}$. Inaczej przedstawiała się sytuacja kobiety po dokonaniu repudium zawinionego przez mężczyznę. W tej sytuacji kobieta nie mogła wyjść za mąż wcześniej niż po upływie roku od dokonania repudium, analogicznie jak w przypadku śmierci męża. Podkreślić należy, że zakaz ten nie był kara, lecz miał na celu wykluczenie ewentualnej watpliwości co do ojcostwa dziecka ${ }^{63}$.

Jeżeli kobieta dla dokonania repudium powołała się na którąś z przyczyn, które pozwalały na jednostronne rozwiązanie małżeństwa $\mathrm{z}$ powodu winy męża, a tej winy nie udowodniłaby, czyli dokonała repudium sine causa, traciła posag i darowiznę ante nuptias na rzecz męża oraz narażała się na dotkliwą sankcję osobistą. Jako niegodna małżeństwa nie mogła ponownie wyjść za mąż przed upływem pięciu lat od dokonania repudium ${ }^{64}$. Jeżeli zaś naruszyła ten zakaz, z braku conubium jej nowego związku nie uważano za małżeństwo, a ona sama popadała w infamię prawną ${ }^{65}$.

\footnotetext{
${ }^{59}$ C. $5,17,8,4 b$.

${ }^{60}$ C. $5,17,8,5$.

${ }^{61}$ C. $5,17,8,4 b-5$.

${ }^{62}$ C. $5,17,8,5$.

${ }^{63}$ C. $5,17,8,4$ b. Zob. P. Niczyporuk, Żałoba i powtórne matżeństwo wdowy w prawie rzymskim, Białystok 2002, s. 128-129. Zob. także J. Zabłocki, In decem mensibus gigni hominem, „Prawo Kanoniczne" 35(1992), nr 3-4, s. 197-210.

${ }^{64}$ C. $5,17,8,4$.

${ }^{65}$ C. $5,17,8,4 \mathrm{a}$.
} 
Podobnie mężczyzna, który nie udowodnił żonie winy, był zobowiązany zwrócić jej posag i tracił darowiznę ante nuptias ${ }^{66}$. Na etapie kodyfikacji za oddalenie żony z nieudowodnionej przyczyny mężczyzna nie ponosił natomiast żadnych sankcji osobistych.

Interesujący jest fakt, że w C. 9,9,34(35) zamieszczone zostało zaledwie jedno zdanie z konstytucji cesarzy Honoriusza i Teodozjusza II z 421 roku, chociaż jej cała treść musiała być znana kodyfikatorom, ponieważ była wcześniej zamieszczona w C.Th. 3,16,2. Interpolowany tekst, jaki znajdujemy w Kodeksie justyniańskim, koresponduje jedynie z pierwszą częścią tejże konstytucji zamieszczonej w Kodeksie teodozjańskim ${ }^{67}$. Pominięte zostały między innymi dyspozycje dotyczące skutków prawnych jednostronnego oddalenia bez prawnej przyczyny.

Z treści tejże konstytucji zamieszczonej w Kodeksie teodozjańskim wynika, że wskutek wniesionego oskarżenia przez jednostronnie oddalonego męża kobieta, która nie była w stanie udowodnić żadnej przyczyny repudium, podlegała karze pozbawienia posagu i darowizn ante nuptias na rzecz męża oraz karze deportacji, do której dołączony został zakaz powtórnego zamążpójścia i korzystania z ius postliminii ${ }^{68}$. Natomiast mężczyzna dopuszczający się tego rodzaju repudium tracił darowiznę ante nuptias, posag i zdolność zawarcia nowego małżeństwa ${ }^{69}$.

Repudium dokonane bona gratia nie powodowało żadnych ujemnych następstw majątkowych dla obydwu stron, oddalona żona zatrzymywała swój posag, a oddalony mąż zachowywał darowiznę ante nuptias. Kobietę w tym przypadku wiązał roczny zakaz zawierania ponownego małżeństwa, jak przy repudium propter causam culpabilem, która wystapiła po stronie męża ${ }^{70}$.

Mężczyzna, który zawarł małżeństwo z kobietą bez posagu, dokonując jej repudium, bez względu na to, czy było ono propter iustam causam czy sine causa był zobligowany prawem do przekazania oddalonej żonie jednej czwartej swojego majątku, gdy jego majątek miał mniejszą wartość niż czterysta funtów złota. Jeżeli majątek przekraczał tę wartość, kobiecie przysługiwał majątek wartości stu funtów złota. Ta sama zasada obowiązywała w odniesieniu do kobiet bez posagu, które bezpodstawnie lub bez jakiejkolwiek przyczyny ośmieliły się oddalić swoich mężów, czyli kobieta winna była wyasygnować na rzecz męża jedną czwartą swojego majątku lub dobra o wartości stu funtów złota. Oddalone strony mogły dobrami tymi swobodnie dysponować, o ile nie miały dzieci ${ }^{71}$.

${ }^{66}$ C. $5,17,8,5$.

${ }^{67}$ Por. C.Th. $3,16,2$ pr.

${ }^{68}$ C.Th. $3,16,2$ pr.

${ }^{69}$ C.Th. 3,16,2,1. A. Gauthier, Le droit romain et son apport à l'édification du droit canonique, Ottawa 1996, s. 45.

${ }^{70}$ C. $5,17,7$; C. $5,17,10$.

${ }^{71}$ C. $5,17,11,1$. 
2. Skutki dotyczące dzieci. Justynian, podobnie jak jego poprzednicy, miał świadomość, że rozwiązywanie małżeństw powagą ludzką, bez względu na formę, w jakiej go dokonywano, nie służyło dobru dzieci. Stąd też dążył do ograniczenia swobody w tym zakresie. Nie osiagnął jednak na etapie kodyfikacji, ani nawet później, do końca zamierzonego celu. W trosce o dobro dzieci postanowił przynajmniej zniwelować jego skutki rozwiązywania małżeństw.

Przede wszystkim w przypadku repudium propter iustam causam zabezpieczył dobro dzieci w taki sposób, że uzyskane przez niewinnego rodzica tytułem kary dobra majątkowe miały być przeznaczone dla dzieci. Taki rodzic mógł swobodnie tymi dobrami rozporządzić testamentowo na rzecz wybranych lub wszystkich swoich dzieci albo je darować jednemu z nich ${ }^{72}$. Nie mógł jednak w żaden sposób ich zbywać ani oddawać w zastaw. Dlatego, gdyby cokolwiek z tych dóbr ubyło, na dziedzicach ciążył obowiązek odszkodowania na rzecz dzieci, które nie były ustanowione dziedzicami lub nie przyjęły spadku, aby w ten sposób dzieci nie ucierpiały na skutek repudium dokonanego z braku rozsądku któregoś z rodziców ${ }^{73}$.

Podobnie w innych przypadkach, gdy z tytułu jednostronnego oddalenia mężowi lub żonie przypadały jakieś dobra, po zawarciu przez nich kolejnego małżeństwa miały one bezwzględnie służyć dzieciom z poprzedniego małżeństwa ${ }^{74}$.

Dobro dzieci i wnuków prawo zabezpieczało także wtedy, gdy w grę wchodziło rozwiązanie małżeństwa zawartego bez posagu. Majątek, który przypadał stronie niewinnej rozpadu małżeństwa, analogicznie jak w innych przypadkach nie mógł być zbyty ${ }^{75}$.

Rozwiązanie małżeństwa wskutek repudium, podobnie zresztą jak i divortium niosło z sobą problem zamieszkania i utrzymania wspólnych dzieci. Justynian, aprobując w D. 43,30,1,3 komentarz Ulpiana do siedemdziesiątej pierwszej księgi ad edictum, uznał za wiążącą zasadę prawa klasycznego, że dzieci, które weszły pod jego władzę, pozostają przy ojcu. Jednocześnie zagwarantował matce prawo zatrzymania dzieci przy sobie, gdyby to było dla nich bardziej korzystne. Gdyby w takiej sytuacji ojciec zażądał wydania dzieci, które były pod opieką matki, przysługiwał jej zarzut procesowy przeciwko żądaniu ich ojca ${ }^{76}$. Nawet gdyby ojcu udało się udowodnić, iż dziecko znajduje się pod jego władzą, sprawa była rozstrzygana na korzyść matki, jeżeli w postępowaniu sądowym wykazała ona niemoralne prowadzenie się ojca. Niewątpliwie niemoralnym zachowaniem było cudzołóstwo, odbywanie schadzek z kobietami, nastawanie na życie matki lub jej bicie, uznane w C. 5,17,8,2 za

\footnotetext{
${ }^{72}$ C. $5,17,8,7$.

${ }^{73}$ C. $5,17,8,7$ a.

${ }^{74}$ C. $5,9,9,1$.

${ }^{75}$ C. $5,17,11,1 \mathrm{c}$.

${ }^{76}$ D. $43,30,1,3$.
} 
zawinioną przyczynę repudium. Niemniej, dziecko przebywające u matki nie wychodziło spod władzy ojca ${ }^{77}$.

Gdyby nie zachodziła żadna z okoliczności uzasadniających pozostawanie ze względów moralnych dzieci u jednego z byłych małżonków, a nie było ich zgody co do tego, przy kim mają one pozostać, wydaje się, że analogicznie jak w przypadku rozwodu, decyzja o tym, kto ma zatrzymać i utrzymywać dzieci należała do sędziego. W żadnym jednak przypadku nie dokonywano podziału dzieci między ojca i matkę ze względu na ich płeć, innymi słowy - sędzia nie był obowiązany przysądzić ojcu synów, a matce $\operatorname{có}^{2} \mathrm{k}^{78}$.

Alimentacja dzieci była naturalnym obowiązkiem rodziców ${ }^{79}$. W przypadku, gdy ojciec wzbraniałby się przed partycypacją w kosztach utrzymania dzieci, kobieta mogła wkroczyć na drogę sądową i zażądać ustalenia wysokości alimentów. Sędzia określał ich wysokość proporcjonalnie do zamożności ojca ${ }^{80}$. Spełnienia obowiązku alimentacyjnego $\mathrm{w}$ czasach Justyniana dochodzono w drodze postępowania extra ordinem.

$\mathrm{Z}$ żądaniem alimentów przed sądem mogły wystapić również dzieci ${ }^{81}$. W kwestii alimentacji Justynian zgodził się z Ulpianem, który na postawione pytania: czy ojciec winien żywić tylko te dzieci, które znajdują się pod jego władza, czy również emancypowane, albo z innych powodów niebędące pod jego władzą, odpowiedział, że prawo do alimentacji ze strony rodziców mają wszystkie dzieci, nie tylko znajdujące się pod władzą ojcowską ${ }^{82}$.

Bez względu na sytuację prawną, w jakiej znaleźli się rodzice i dzieci po rozwiązaniu małżeństwa w drodze repudium, rodziców wiązała formuła mówiąca, że władza ojcowska powinna się opierać na pobożności, a nie bezwzględności ${ }^{83}$. Digesta nakazywały uznać za morderców dzieci nie tylko tych rodziców, którzy popełniali przestępstwo przerywania ciąży, lecz również tych, którzy porzucali urodzone dzieci, odmawiając im pożywienia, albo wystawiali je w miejscach publicznych na cudze miłosierdzie, którego sami nie mieli ${ }^{84}$. Oczywiście problem niechcianych dzieci mógł wystąić zarówno poza małżeństwem, w małżeństwie, jak i po podjęciu decyzji o jego rozwiązaniu, także w drodze repudium.

${ }^{77}$ D. $43,30,3,5$.

${ }^{78}$ C. $5,24,1$.

${ }^{79}$ C. 5,25,1 (Imp. Pius A. Basso): Parentum necessitatibus liberos sucurrere iustum est. Zob.

G. Kuleczka, Prawo rzymskie epoki..., s. 101-103.

${ }^{80}$ C. $5,25,3$.

${ }^{81}$ D. $25,3,5$ pr.

${ }^{82}$ D. 25,3,5,1. M.G. Zoz, analizując przytoczony fragment Digestów, zauważa, że Ulpian nie wymienił wszystkich możliwych przypadków obowiązku alimentacji względem dzieci, ale z tego pominięcia nie można wyciagać wniosków a contrario, że w innych przypadkach taki obowiązek nie istniał. Zob. M.G. Zoz, In tema di obbligazioni alimentari, BIDR 73-74 (1970-71), s. 328.

${ }^{83}$ D. $48,9,5$.

${ }^{84}$ D. $25,3,4$. 
Reasumując przeprowadzone rozważania na temat repudium $\mathrm{w}$ okresie kodyfikacji justyniańskiej, należy stwierdzić, że Justynian nie wzruszył na tym etapie w sposób radykalny fundamentów starego prawa w tym zakresie. Niemniej należy mu oddać to, że potrafił zachować dystans wobec doktryny Kościoła i umiejętnie wyważył potrzeby społeczne, przy jednoczesnym dostrzeżeniu tego, że rozpad małżeństwa w drodze repudium jest złem koniecznym, z powodu którego w sposób niezawiniony cierpią dzieci. Dobro dzieci (favor liberorum) było dla niego jednym z głównych motywów ograniczenia swobody jednostronnego oddalania małżonków.

Utrzymane przez niego w mocy przepisy dawnego prawa w dalszym ciagu dyskryminowały kobiety, zwłaszcza w zakresie sankcji karnych za nieusprawiedliwione repudium.

Niewątpliwym wkładem Justyniana w uporządkowanie rozwiązywania małżeństw było uznanie niezdolności męża do współżycia małżeńskiego jako podstawy repudium bona gratia ze strony kobiety.

Jako pozytywne należy także ocenić wprowadzenie do prawa rzymskiego przepisów służących zapewnieniu środków do życia oddalonemu małżonkowi i wspólnym dzieciom w przypadku rozpadu małżeństwa zawartego bez posagu.

Poczynione przez Justyniana w okresie kodyfikacji kroki na drodze reformy prawa małżeńskiego i rodzinnego w kwestii repudium, bez wątpienia ważne, stanowią preludium zasadniczej reformy, której dokonał on w Nowelach.

\section{REPUDIUM AND ITS LEGAL CONSEQUENCES IN LIGHT OF JUSTINIAN CODIFICATION}

\section{S u m m a r y}

Among the allowable forms of termination of marriage in Justinian law were repudium and divortium. At the time of Christian emperors, however, under the influence of the views of the Christian Church, those practices were often criticised and there were attempts to limit, or restrict their use.

The paper deals with repudium at the stage of codification. It must be said that at that stage Justinian did not introduce any radical changes to the existing foundations of the previous regulations. However, he distanced himself from the Church doctrine, and skilfully assessed the social expectations and needs, pointing, at the same time, that termination of marriage is a necessary evil, and it is the innocent children who suffer as a result thereof. Hence the welfare of the children (favor liberorum) was for Justinian one of the main reasons for restricting the right of a unilateral repudiation of marriage. 
The provisions of the former law that Justinian decided to uphold, were discriminatory against women, particularly with regards to penal sanctions for unjustified repudium.

Undoubtedly, his major contribution to the regulation of matrimonial law was recognition of the husband's incapacity of fulfilling his marriage duties as a ground for the wife's repudium bona gratia. Another provision that is noteworthy and for which Justinian must be acknowledged is introduction of provisions securing alimony to the abandoned spouse and children in the event of a marriage without dowry.

The measures undertaken by Justinian at the codification stage of the reformed matrimonial and family law constitute an unquestioned preliminary draft of the subsequent reformed law made in the Novellae.

\section{REPUDIUM ET SES EFFETS JURIDIQUES À LA LUMIÈRE DES CODIFICATIONS DE JUSTINIEN}

\section{$\mathrm{R}$ é s u m é}

Les formes de la dissolution du mariage reconnues par le droit de Justinien sont les suivantes: repudium et divortium. Sous l'influence des idées prêchées par les Pères de l'Église, leur pratique à l'époque des empereurs chrétiens rencontre des critiques et doit faire face aux tentatives de les limiter.

Le présent article porte sur la problématique du repudium à l'étape de la codification. À ce niveau-là, Justinien n'a pas changé de manière radicale les fondements de l'ancien droit. Il a par contre su prendre du recul par rapport à la doctrine de l'Église et avec intelligence, équilibrer les besoins sociaux, tout en s'apercevant que la rupture du mariage suite au repudium était un mal nécessaire, à cause duquel souffraient les enfants innocents. Le bien des enfants (favor liberorum) est pour Justinien l'un des motifs principaux qui conduit à une liberté limitée permettant de renvoyer unilatéralement le conjoint.

Les dispositions du droit concerné maintenues en vigueur par Justinien continuaient à discriminer les femmes, notamment en matière des sanctions pénales pour une repudium non justifiée. Par contre, la contribution incontestable de Justinien à la mise en ordre de la dissolution du mariage était la reconnaissance de l'incapacité du mari à avoir une vie conjugale commune ce qui permettait d'opérer une repudium bona gratia par la femme. Il convient également de citer ici un phénomène positif, soit l'introduction dans le droit romain des dispositions visant à sécuriser les moyens de vivre au conjoint renvoyé ainsi qu'aux enfants communs, en cas de rupture d'un mariage conclu sans dot.

Les mesures entreprises par Justinien au moment de la codification, orientées sur la réforme du droit matrimonial et de la famille, relatives à la question du repudium, étant sans aucun doute importantes, préludent sa réforme principale réalisée dans les Novelles de l'empereur. 